Хірургічна стоматологія

удК 616 - 001+616.31+617.52 - 001

DOI 10.11603/2311-9624.2018.3.9334

(C). Р. Назаревич, Р. З. Огоновський, Х. Р. Погранична

Львівський національний медичний університет імені Данила Галицького (maxnaz34@gmail.com)

\title{
Удосконалення діагностики та лікування сенсорних порушень середньої зони обличчя у хворих з ізольованими переломами дна очниці
}

Резюме. Серед переломів кісток середньої зони обличчя ізольовані переломи очниці складають 1128 \% і займають третє місце після переломів виличної кістки й дуги та кісток носа. За нашими спостереженнями, ізольовані переломи кісток дна очниці бувають у 8,9 \% випадків. При «вибуховому» переломі очниці наявність клінічних ознак невропатії підочноямкового нерва є важливим патогномотичним симптомом, що вказує на локалізацію перелому на дні очниці. До основних факторів, що визначають при периферійних травматичних невропатіях, швидкість і якість спонтанного відновлення порушених функцій, належать: ступінь ушкодження нервового провідника, рівень ураження, ішемія тканин, характер ушкоджувального агента. При перетисканні нерва ступінь порушення провідності залежить перш за все від тривалості й інтенсивності компресії.

Мета дослідження - удосконалити діагностику та місцеве лікування травматичних ушкоджень підочноямкового та виличного нервів у хворих з ізольованими переломами очниці.

Матеріали і методи. Клінічні, рентгенологічні, нейрофункціональні та біохімічні методи дослідження були проведені у 19 хворих віком від 20 до 65 років з ізольованими «вибуховими» переломами дна очниці. Інтенсивність набряку та крововиливу в ділянках очниць оцінювали за методикою Mohsen Rajati et al. (2013). Усім хворим проводили комп’ютерну томографію кісток лицевого черепа iз їх 3D-реконструкцією. В них виявляли рентгенологічні типи переломів дна очниці згідно 3 класифікацією G. F. Fueger та A. T. Milauskas (1966). Ступені ураження підочноямкового та виличного нервів оцінювали за класифікацією Н. Seddon (1943), виділяли при цьому 3 види ускладнення: нейрапраксію, аксонотмезіс, нейротмезіс. Ступінь ушкодження гілок верхньощелепного нерва визначали за даними електрофізіологічних тестів за методикою Н. К. Нечаевой та співав. (2014). Показники їх чутливості в нормі - 25-35 мкА. Електродіагностику чутливості шкірних гілок верхньощелепного нерва здійснювали в місцях їх виходу на поверхню обличчя за допомогою апарату для низькочастотної електротерапії «Радиус-01 ФТ» (Білорусь) в режимі роботи - електростимуляція. Електроодонтометрію зубів на відповідному боці верхньої щелепи проводили за допомогою цифрового електроодонтометра «Pulptester» (Тайвань). У периферійній венозній крові хворих визначали концентрацію нейронспецифічної енолази (НСЕ), що підвищується при руйнуванні нейронів. Ї̈̈ досліджували імунохімічним методом з електрохемілюмінесцентною детекцією, для цього застосовували аналізатор і тест-систему Cobas 6000, Roche Diagnostics (Швейцарія). Референтне значення HCE- до 16,3 нг/мл.

Статистичну обробку отриманих результатів досліджень проводили за допомогою комп’ютерної програми статистичних обчислень Statistica 8.

Результати досліджень та їх обговорення. Ми виявили легкий ступінь (нейрапраксію) ушкодження підочноямкового нерва у 12 пацієнтів. Променеве дослідження фіксувало проходження лінії перелому через підочноямковий канал чи борозну в 7 випадках, а у 5 пацієнтів виявлено лінію перелому, яка перетинала підочноямкову щілину. За рентгенологічною класифікацією G. F. Fueger та A. T. Milauskas хворі мали другий, четвертий та шостий типи переломів кісток дна очниці. Уміст у крові концентрації нейронспецифічної енолази не виходив за верхню межу норми - $(15,9 \pm 1,4)$ нг/мл $(\mathrm{p}>0,05)$. Порушення чутливості зубів та м’яких тканин у зоні іннервації підочноямкового та виличного нервів у всіх хворих цієї групи носили тимчасовий характер. Після курсу терапії швидше зменшувався набряк м’яких тканин очниці та розсмоктувались гематоми. Чутливість ушкоджених нервів повністю відновлювалася через 3-4 тижні. Наявність аксонотмезісу підочноямкового та виличного нервів у 7 пацієнтів став причиною виникнення виражених сенсорних порушень у м'яких тканинах підочної й виличної ділянок, втрати чутливості в зубах на верхній щелепі на боці ушкодження. Серед виявлених причин цих патологічних змін визначальним було їх перетискання кістковими відламками дна очниці, які були зміщені у верхньощелепний синус. Дані, отримані при комп’ютерній томографії, повністю корелювали з результатами клініко-електрофізіологічної діагностики. У крові таких хворих зростала концентрація нейронспецифічної енолази, що виходила за верхню межу норми - $(20,6 \pm 1,7)$ нг/мл (р<0,01). У цієї категорії обстежених чутливість, як правило, відновлювалася в повному обсязі через 1,5-2 місяці після операцій за реконструкцією дна очниці та курсу медикаментозної терапії.

Висновки. Застосування електрофізіологічних тестів та дослідження в крові маркера ушкодження нервової тканини - нейронспецифічної енолази, дозволяють виявити ступінь ушкодження підочно- 
ямкового та виличного нервів у хворих з ізольованими переломами дна очниці. Місцеве застосування фібринолітичного препарату «Гемаза» та гомеопатичного засобу «Траумель С» прискорює розсмоктування гематоми очниці, швидше ліквідуються клінічні симптоми запалення та покращує ефективність лікування невриту підочноямкового й виличного нервів.

Ключові слова: ізольований перелом дна очниці; травматична невропатія підочноямкового й виличного нервів; гематома очниці; електросенсометрія; нейронспецифічна енолаза; гемаза, траумель С.

\author{
(С). Р. Назаревич, Р. З. Огоновский, Х. Р. Погранична
}

Львовский национальный медицинский университет имени Данила Галицкого

\title{
Совершенствование диагностики и лечения сенсорных нарушений средней зоны лица у больных с изолированными переломами дна глазницы
}

Резюме. Среди переломов костей средней зоны лица изолированные переломы глазницы составляют 11-28 \% и занимают третье место после переломов скуловой кости и дуги и костей носа. По нашим наблюдениям, изолированные переломы костей дна глазницы встречались в 8,9 \% случаев. При «взрывном» переломе глазницы наличие клинических признаков невропатии подглазничного нерва является важным патогномотичным симптомом, указывающим на локализацию перелома на дне глазницы. К основным факторам, которые определяют при периферических травматических невропатиях, скорость и качество восстановления нарушенных функций, относятся: степень повреждения нервного проводника, уровень поражения, ишемия тканей, характер повреждающего агента. При сдавливании нерва степень нарушения проводимости зависит в первую очередь от интенсивности и продолжительности компрессии.

Цель исследования - усовершенствовать диагностику и местное лечение травматических повреждений подглазничного и скулового нервов у больных с изолированными переломами дна глазницы. Материалы и методы. Клинические, рентгенологические, нейрофункциональные и биохимические методы исследования были проведены у 19 больных в возрасте от 20 до 65 лет с изолированными «взрывными» переломами дна глазницы. Интенсивность отека и кровоизлияния в участках глазниц оценивали по методике Mohsen Rajati et al. (2013). Всем больным проводили компьютерную томографию костей лицевого черепа с их 3D-реконструкцией. В них определяли рентгенологические типы переломов дна глазницы согласно классификации G. F. Fueger и A. T. Milauskas (1966). Степень поражения подглазничного и скулового нервов оценивали по классификации H. Seddon (1943). При этом выделяют 3 вида осложнений: нейрапраксию, аксонотмезис, нейротмезис. Степень повреждения ветвей верхнечелюстного нерва определяли с помощью электрофизиологических тестов по методике Н. К. Нечаевой и соавт. (2014). Показатели их чувствительности в норме - 25-35 мкА. Электродиагностику чувствительности кожных ветвей верхнечелюстного нерва осуществляли в местах их выхода на поверхность лица с помощью аппарата для низкочастотной электротерапии «Радиус-01 ФТ» (Белорусь) в режиме работы электростимуляция. Электроодонтометрию зубов на соответствующей стороне верхней челюсти проводили с помощью цифрового электроодонтометра «Pulptester» (Тайвань). В периферической венозной крови больных определяли концентрацию нейронспецифической энолазы (НПЭ), которая повышается при разрушении нейронов. Ее исследовали иммунохимическим методом с электрохемилюминесцентной детекцией, для этого применяли анализатор и тест-систему Cobas 6000, Roche Diagnostics (Швейцария). Референтные значения НСЕ - до 16,3 нг/мл. Статистическую обработку полученных результатов исследований проводили с помощью компьютерной программы статистических вычислений Statistica 8.

Результаты исследований и их обсуждение. Нами выявлено легкую степень (нейрапраксию) повреждения подглазничного нерва у 12 пациентов. Ренгенологическая диагностика фиксировала прохождения линии перелома через подглазничный канал или борозду в 7 случаях, а у 5 пациентов выявлено линию перелома, которая пересекала подглазничную щель. По рентгенологической классификации G. F. Fueger и A. T. Milauskas, больные имели второй, четвертый и шестой типы переломов костей дна глазницы. Содержание в крови концентрации нейронспецифической энолазы не выходил за верхнюю границу нормы - $(15,9 \pm 1,4)$ нг/мл $(\mathrm{p}<0,05)$. Нарушение чувствительности зубов и мягких тканей в зоне иннервации подглазничного и скулового нервов у всех больных этой группы носили временный характер. После курса терапии быстрее уменьшался отек мягких тканей глазницы и рассасывались гематомы. Чувствительность поврежденных нервов полностью восстанавливалась через 3-4 недели. Возникновение аксонотмезиса подглазничного и скулового нервов у 7 пациентов стал причиной стойких сенсорных нарушений в мягких тканях подглазничной и скуловой области, потери чувствительности в зубах на верхней челюсти на стороне повреждения. Среди выявленных 


\section{Хірургічна стоматологія}

причин этих патологических изменений определяющим была их компрессия костными отломками дна глазницы, которые были смещены у верхнечелюстной синус. Данные, полученные при компьютерной томографии, полностью коррелировали с результатами клинико-электрофизиологической диагностики. В крови таких больных увеличивалась концентрация нейронспецифической энолазы, концентрация которой выходила за верхнюю границу нормы - $(20,6 \pm 1,7)$ нг/мл (р<0,01). В этой категории обследованных чувствительность, как правило, восстанавливалась в полном объеме через 1,5-2 месяца после операций по реконструкции дна глазницы и курса медикаментозной терапии.

Выводы. Применение электрофизиологических тестов и определение в крови маркера повреждения нервной ткани - нейронспецифической энолазы, позволяют определить степень повреждения подглазничного и скулового нервов у больных с изолированными переломами дна глазницы. Местное применение фибринолитического препарата «Гемаза» и гомеопатического средства «Траумель С» ускоряет рассасывание гематомы глазницы, быстрее ликвидируются клинические симптомы воспаления и улучшается эффективность лечения неврита подглазничного и скулового нервов.

Ключевые слова: изолированный перелом дна глазницы; травматическая невропатия подглазничного и скулового нервов; гематома глазницы; электросенсометрия; нейронспецифическая энолаза; гемаза; траумель С.

\section{R. Nazarevych, R. Z. Ogonovsky, Kh. R. Pohranychna}

Danylo Halytskyi Lviv National Medical University

\section{Improvement of diagnosis and treatment of the middle face zone sensory disorders in patients with izolated orbital bottom fractures}

Summary. Among the bone fractures of the midface, blow-out fractures amount to 11-28 \% and occupy the third place after zygomatic and zygomatic arch fractures and fractures of nasal bones. According to our observations for the period from 2014 till 2017, among patients who were treated in the Department of Maxillofacial Surgery of the Communal City Clinical Emergency Hospital of Lviv with bone fractures of the middle field of facial skull, blow-out fractures occurred in $8.9 \%$ of cases. With the blow-out fracture, the presence of clinical signs of neuritis of the infraorbital nerve is an important pathognomonic symptom indicating the localization of bone fracture at the orbital floor. The main factors that determine the rate and quality of unprompted recovery of affected functions and, accordingly, the scope and target of the therapeutic interventions in cases of peripheral traumatic neuropathies include: the degree of nerve guide lesion, the level of destruction, tissue ischemia, the kind of the disturbing factor. When the nerve is constricted, the degree of conductivity failure depends primarily on the duration and intensity of constriction injury.

The aim of the study - to improve diagnostics and local treatment of traumatic lesions of infraorbital and zygomatic nerves in patients with blow-out fractures.

Materials and Methods. Clinical, radiological, neurofunctional and biochemical methods of research were applied in 19 patients, aged 20 to 65 years, with blow-out fractures. Intensity of edema and hemorrhage in the area of the orbital cavity was evaluated using the methodology of Mohsen Rajati et al. (2013). After hospitalization, all patients underwent computer tomography of the facial skull bones with 3D reconstruction. There were found roentgenologic fractures of orbital floor according to the classification of G.F. Fueger and A.T. Milauskas (1966). The degree of destruction of infraorbital and zygomatic nerves (with regard to dynamic clinical observations) was assessed by classification of H. Seddon (1943), which allows determining the degree of lesion of the nerve trunk according to the changes in conductivity in each of its segments; 3 types of complications are distinguished: neurapraxia, axonotmesis, neurotmesis. The degree of lesion of the branches of the maxillary nerve was determined according to the data of electrophysiological tests according to Nechaieva N.K. et al. (2014). The reference values are between 25-35 $\mu \mathrm{A}$.

Electroodontometry of teeth on the corresponding side of the upper jaw was carried out using a portable electroodontometer «Pulptester» (Taiwan). Electrodiagnostics of sensitivity of skin branches of maxillary nerve was carried out in their exit sites on the surface of face using low-frequency electrotherapy device «Radius-01 FT» (Belarus) in the mode of electrical stimulation. In the peripheral venous blood of patients, there was determined the concentration of neuron-specific enolase (NSE), which is a neuron-specific isoform of enolase found in neurons. It was analyzed by an immunochemical method with the use of electrochemiluminescent detection, using a Cobas 6000 analyzer and test system by Roche Diagnostics (Switzerland). Reference value of NSE - up to $16.3 \mathrm{ng} / \mathrm{ml}$.

In the acute flow period of traumatic process in the presence of pronounced hemorrhage in the orbital cavity and perifocal edema during comprehensive treatment, for the prevention of the occurrence of spike processes in the damaged branches of maxillary nerve, the patients were injected parabulbarly, along the orbital floor, to infraorbital sulcus, where the homonymic nerve lies, fibrinolytic medication Gemaza (recombinant prourokinase) -1 time per day, over $5000 \mathrm{ME}$ in $0.5 \mathrm{ml}$ of $0.9 \%$ solution of sodium chloride on a daily basis for $4-5$ 
days. In the subacute period - the solution of Traumeel S was injected to the infraorbital and zygomaticofaciale foramen by $2.2 \mathrm{ml}$ in a day, on a course of treatment -6 injections. The drug has anti-inflammatory, analgesic, anti-exudative, immuno-corrective and reparative effect. The effect of the drug is based on the activation of the body defences and normalization of disturbed functions due to substances of vegetable and mineral origin, which are part of the drug.

Statistical processing of the results of research was carried out with the help of a computer program for statistical computation «Statistica 8».

Results and Discussion. The first, mild degree - neurapraxia - has been detected in 12 patients. Injury to the nerve might have occured as a result of constriction of the nerve trunk due to pronounced swelling and bruises. Imaging study recorded actual passing of fracture through the infraorbital canal and the infraorbital sulcus in 7 cases, and in 5 patients there was revealed a fracture line that crossed the infraorbital fissura. These patients had the second, fourth and sixth types of fractures according to the radiological classification of G.F. Fueger and A.T. Milauskas. Content of concentrations of neuron-specific enolase in blood did not exceed the upper limit of the norm - $(15.9 \pm 1.4) \mathrm{ng} / \mathrm{ml}(\mathrm{p}>0.05)$. Violation of the sensitivity of teeth and soft tissues in the area of innervation of infraorbital and zygomatic nerves in all patients in this group were temporary. After a course of local therapy with Gemaza and Traumeel S, edema of soft tissues of the orbital cavity decreased and hematoma waned faster. The sensitivity of the damaged nerves was completely restored after 3-4 weeks. The presence of axonotmesis of the infraorbital and zygomatic nerves in 7 patients was the cause of expressed sensory abnormalities in soft tissues of infraorbital and zygomatic areas, loss of sensitivity in the teeth of the upper jaw on the side of the lesion. Among the revealed causes of these pathological changes, the determinant factor was their constriction by bone fractures of the orbital floor which were displaced in the maxillary sinus. Data obtained in computer tomography fully correlated with the results of clinical and electrophysiological diagnostics. In the blood of such patients, the concentration of neuron-specific enolase increased, which was beyond the upper limit of the norm - $(20.6 \pm 1.7) \mathrm{ng} / \mathrm{ml}(\mathrm{p}<0.01)$. In this category of the examined patients sensitivity, as a rule, was restored in full after 1.5 - 2 months after surgery treatment for the reconstruction of the orbital floor.

Conclusions. Application of electrophysiological testing and blood research of the marker of nervous tissue lesion - neuron-specific enolase - allow determining the degree of lesion of infraorbital and zygomatic nerves in patients with blow-out fractures. The local combined application of fibrinolytic agent Gemaza and homeopathic medication Traumeel S in the comprehensive treatment accelerates the elimination of clinical symptoms of inflammation, orbital hematoma waning, and prevents the development of neuritis of infraorbital and zygomatic nerves.

Key words: blow-out fracture; traumatic neuropathy of infraorbital and zygomatic nerves; ocular hematoma; electrodiagnostics of sensitivity; neuron-specific isoform of enolase; Gemaza; Traumeel S.

Вступ. Ушкодження кісток очниці поєднується $з$ травмою інших кісток лицевої частини черепа (вилично-верхньощелепного, носо-лобно-етмоїдального комплексів) у 40 \% випадків [1-4]. Серед переломів кісток середньої зони обличчя ізольовані переломи очниці складають 11-28 \% й займають третє місце після переломів виличної кістки й дуги та кісток носа [5]. Ізольований перелом очниці виникає, як правило, внаслідок прямого удару в напрямку до очного яблука. Під впливом механічної енергії відбувається руйнування анатомічної цілості дна очниці, оскільки їі аркоподібна верхня стінка більш стійка до деформацій, ніж майже плоске дно, яке легше деформується і ламається. Його кістки та прилеглі м'які тканини вдавлюються в підлеглу порожнину верхньощелепної пазухи. Медіальна стінка також є тонка, але ззаду за типом контрфорсів, їі зміцнюють комірки решітчатої кістки [1]. Такий тип перелому очниці отримав назву «очноямковий вибуховий» перелом (рис. 1).
За нашими спостереженнями, за період із 2014 до 2017 р. серед хворих, які перебували на лікуванні у відділенні щелепно-лицевої хірургї комунальної міської клінічної лікарні швидкої медичної допомоги м. Львова із переломами кісток лицевого черепа, ізольовані

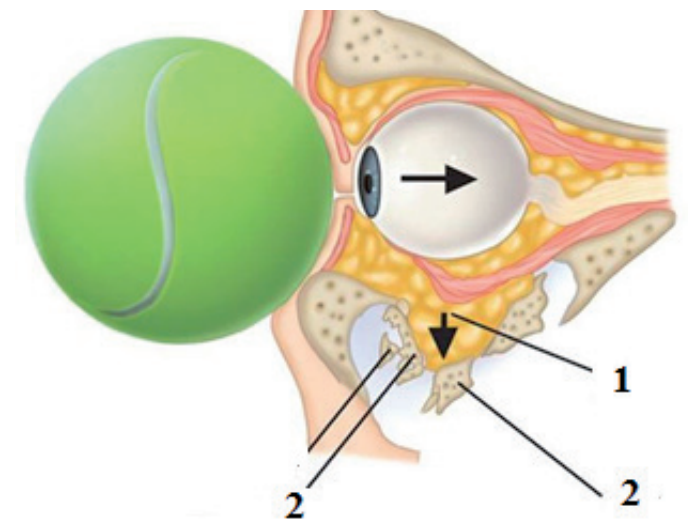

Puc. 1. Механізм виникнення ізольованого «вибухового» перелому дна очниці: 1 - зміщення м'яких тканин дна очниці; 2 - ушкодження та зміщення кісток дна очниці.

ISSN 2311-9624. Клінічна стоматологія. 2018. № 3 
«вибухові» переломи кісток дна очниці були у 12,5 \% випадків. Переломи стінок очниці практично завжди супроводжуються струсом головного мозку. При такій локалізації травми обличчя найхарактернішими є наступні місцеві клінічні симптоми: гематома очниці та періорбітальної ділянки - 89,65 \%, набряк м'яких тканин - 96,55 \%, диплопія - 58,1 \%, розлади чутливості м'яких тканин, прилеглих до очниці (гіпестезія, парестезія), в зоні іннервації підочноямкового нерва - 35,5 \%, обмежений рух очних яблук $-9,7 \%$, енофтальм - 3,2 \% [6, 7]. При травмі очниці наявність клінічних проявів невропатії підочноямкового нерва $\epsilon$ важливим патогномонічним симптомом, що вказує на можливу локалізацію перелому на дні очниці [8]. До основних факторів, які визначають при травматичних невропатіях, тривалість і якість відновлення функцій нерва, належать: характер ушкоджувального агента, тяжкість ушкодження нервового стовбура, рівень ураження, ішемія тканин. При перетисканні нерва ступінь порушення провідності залежить перш за все від тривалості й інтенсивності компресії [9]. Необхідно також враховувати топографо-анатомічні особливості локалізації підочноямкового нерва на дні очниці, який має індивідуальну мінливість положення в підочноямковій борозні та одноіменному каналі $[10,11]$. При тривалому стисненні нервового стовбура розвиваються дегенеративні зміни [12]. На основі ретроспективного аналізу історій хвороб, ми встановили, що частота виникнення хронічних травматичних невритів підочноямкового та виличного нервів у хворих із "вибуховим" переломом дна очниці сягає 28,6 \% випадків. При традиційному (стандартному) лікуванні цього патологічного стану відновлення функції ушкоджених нервів відбувається через 2,53 місяці.

Метою дослідження було удосконалити діагностику та місцеве лікування травматичних ушкоджень підочноямкового та виличного нервів у хворих з ізольованими переломами дна очниці.

Матеріали і методи. Клінічні, рентгенологічні, нейрофункціональні та біохімічні методи дослідження були проведені у 19 хворих віком від 20 до 65 років 3 ізольованими «вибуховими" переломами дна очниці. Інтенсивність набряку та крововиливу в ділянках очниць оцінювали за методикою Mohsen Rajati та співавт. [13], при якій розрізняють легкі, помірні та тяжкі їх клінічними прояви. Для цього оцінювали вираження набряку повік, субкон'юнктивального крововиливу й періорбітального екхімозу (підшкірного крововиливу) (табл.). Після госпіталізації усім хворим проводили комп’ютерну томографію кісток

Таблищя. Клінічна оцінка ступеня вираження крововиливу в ділянку очниці (3a Mohsen Rajati et al., 2013)

\begin{tabular}{|c|c|c|c|}
\hline \multirow{2}{*}{ Клінічний прояв } & \multicolumn{3}{|c|}{ Ступінь вираження крововиливу в ділянку очниці } \\
\hline & слабкий & помірний & виражений \\
\hline Набряк повік & $\begin{array}{c}\text { Нормальна } \\
\text { пальпебральна щілина }\end{array}$ & $\begin{array}{c}\text { Звужена пальпебраль- } \\
\text { на щілина }\end{array}$ & $\begin{array}{c}\text { Закрита пальпебральна } \\
\text { щілина }\end{array}$ \\
\hline Періорбітальний екхімоз & $\begin{array}{c}\text { Уражає менше полови- } \\
\text { ни площі } \\
\text { шкірних покривів у } \\
\text { ділянці очниці }\end{array}$ & $\begin{array}{c}\text { Уражає половину } \\
\text { площі } \\
\text { шкірних покривів у } \\
\text { ділянці очниці }\end{array}$ & $\begin{array}{c}\text { Тотальне ураження } \\
\text { шкірних покривів у ді- } \\
\text { лянці очниці }\end{array}$ \\
\hline $\begin{array}{l}\text { Субкон’юнктивальний } \\
\text { крововилив }\end{array}$ & $\begin{array}{l}\text { Уражає менше полови- } \\
\text { ни площі кон’юнктиви }\end{array}$ & $\begin{array}{c}\text { Уражає половину пло- } \\
\text { щі кон’юнктиви }\end{array}$ & $\begin{array}{c}\text { Тотальне ураження } \\
\text { кон’юнктиви }\end{array}$ \\
\hline
\end{tabular}

лицевого черепа з їх 3D-реконструкцією. У пацієнтів виявляли рентгенологічні типи переломів дна очниці за класифікацією G. F. Fueger та A. T. Milauskas [1, 14]: перший тип (класичний) - перелом внутрішньої половини нижньої стінки очниці, лінія перелому проходить медіальніше каналу підочноямкового нерва, другий тип - лінія перелому доходить до каналу підочноямкового нерва, третій - перелом нижньої та внутрішньої стінки очниці, четвер- тий тип - повний (тотальний) перелом кісток дна очниці, п’ятий - атипові форми перелому (прямокутні, трикутні, зірчаті), шостий тип лінійні переломи дна очниці без зміщення відламків (Ү-подібний, латеральний лінійний).

Ступені ураження підочноямкового та виличного нервів (з урахуванням динамічного клінічного спостереження) оцінювали за класифікацією H. Seddon (1943) [15], яка дозволяє визначити ступінь ушкодження нервового 
стовбура за змінами провідності в кожному його сегменті й виділяють при цьому 3 види ускладнення: 1) нейрапраксія - переважне ураження мієлінової оболонки, що не призводить до загибелі аксона. Найчастіше має місце при компресії чи травмі легкого ступеня. Прояви: зниження вібраційної, пропріоцептивної, іноді - тактильної чутливості (больова чутливість страждає значно рідше), а також парестезії. Симптоми поступово регресують у міру відновлення мієліну; 2) аксонотмезис - переважне ураження чи загибель аксона при збереженні епіневрія, периневрія, ендоневрія та шванівських клітин. Найчастіше має місце при компресії чи розтягуванні нерва. Виникає при травмі середнього ступеня тяжкості. Прояви: більш виразні порушення чутливої та вегетативної функцій нерва. Відновлення функцій не завжди повне, може продовжуватися упродовж декількох місяців; 3) нейротмезис - розрив нерва з перетином аксона та оболонок. Прояви: повна втрата перелічених функцій нерва. Через 2-3 тижні після розриву нервового стовбура на центральному кінці утворюється травматична неврома. Прогноз відновлення функцій несприятливий. Ступінь ушкодження гілок верхньощелепного нерва визначали за даними електрофізіологічних тестів за методикою Н. К. Нечаєвой та співавт. [16].

Отримані значення електросенсометрії інтерпретуються наступним чином: показники електрочутливості шкіри обличчя в нормі становлять 25-35 мКА, пульпи зубів - 6-10 мКА. При значеннях показників електропотенціалу (ЕП) шкіри обличчя - 45-55 мкА й електроодонтометрії (ЕОД) зубів 12-25 мкА діагностують тимчасове порушення провідності нерва, що свідчить про легкий ступінь ушкодження нерва (нейрапраксія); середній ступінь ушкодження нерва (аксонотмезис) - ЕП шкіри обличчя - 55-80 мКА і ЕОД зубів - 26-50 МКА; тяжкий ступінь ушкодження нерва (нейротмезис) - показники ЕОД зубів 51-100 мКА, ЕП шкіри обличчя - 80-150 мкА. Електродіагностику чутливості поверхневих гілок верхньощелепного нерва проводили шляхом накладання датчиків на шкіру в проекції їх виходу на поверхню обличчя (рис. 2). Для цього використовували апарат «Радиус-01 ФТ» (Білорусь) в режимі роботи - електростимуляція. Для цього було вибрано наступні орієнтири: чутливість вилично-скроневого нерва тестували на $(15,0 \pm 0,5)$ мм латеральніше лобово-виличного шва й на 23,0+0,5 мм вище верхнього краю виличної

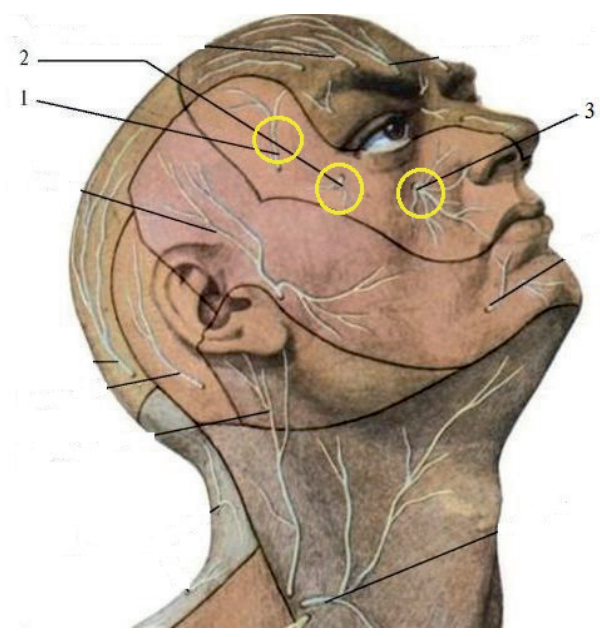

Рис. 2. Електродіагностика чутливості поверхневих гілок верхньощелепного нерва. Місця накладання датчиків на шкірі обличчя в проекціях виходу: 1 вилично-скроневого нерва; 2 - вилично-лицевого нерва; 3 - підочноямкового нерва.

дуги $[17,18]$, вилично-лицевий нерв тестували в точці, що розташована на $(8,5 \pm 0,5) \mathrm{Mм}$ латеральніше від нижньо-зовнішнього кута очниці й нище на $(24,0 \pm 0,5)$ мм від лобово-виличного шва [19, 20], а підочноямковий нерв діагностували в точці, яка розташована на $(6,7 \pm 1,62)$ мм нище від нижнього краю очниці (на рівні вилично-верхньощелепного шва) й на $(17,5 \pm 0,5)$ мм медіальніше від грушоподібного отвору [21, 22].

Вимір електрочутливості пульпи зубів на відповідному боці верхньої щелепи проводили шляхом електроодонтодіагностики (ЕОД) за допомогою портативного цифрового електроодонтометра «Pulptester» (Тайвань).

У периферійній венозній крові хворих визначали концентрацію нейронспецифічної енолази (НСЕ), що є нейронспецифічною ізоформою енолази, яка буває в нейронах. Рівень НСЕ підвищується при захворюваннях нервової системи, що супроводжуються досить швидким руйнуванням нейронів, тому використовується в діагностиці та оцінці прогнозу відновлення при ураженнях нервової системи різного генезу (травматичного, ішемічного). Його досліджували імунохімічним методом 3 електрохемілюмінесцентною детекцією, для цього застосовували аналізатор і тест-систему Cobas 6000, Roche Diagnostics (Швейцарія). Peферентне значення НCE - до 16,3 нг/мл.

Усім хворим у період гострої реакції на травму загально призначали антибіотикотерапію (кліндаміцин - по 300 мг 2 рази на добу протягом 7-8 днів), знеболювальну та протизапальну терапії (кетопрофен - по 100 мг 2 рази на

ISSN 2311-9624. Клінічна стоматологія. 2018. № 3 


\section{Хірургічна стоматологія}

добу протягом 5-6 днів), протинабрякову терапію ( L-лізину есцинату - внутрішньовенно по 5-10 мл препарату, розведеного у 10-20 мл 0,9 \% розчину натрію хлориду 1 раз на добу упродовж 4-5 днів).

На етапі реабілітації хворим призначали: вітамінотерапію (вітаміни $\mathrm{B}_{1}, \mathrm{~B}_{6}, \mathrm{~B}_{12}$ ), для покращення трофіки і регенерації аксонів нервової тканини: нікотинову кислоту - внутрішньом'язово по 0,01 г 1-2 рази на день, келтікан - по 1 капсулі 2 рази на добу упродовж 10 діб.

Для профілактики виникнення спайкових процесів у ділянках ушкодження гілок верхньощелепного нерва вводили парабульбарно до підочноямкової борозни, де залягає одноіменний нерв, фібринолітичний препарат «Гемаза» (рекомбінантну проурокіназа) - по 5000 ME в 0,5 мл 0,9 \% розчину хлориду натрію 1 раз на добу упродовж 4-5 днів. Після завершення курсу місцевого введення цього препарату, для швидшої ліквідації запальної реакції у періорбітальній ділянці та оптимізації репаративних процесів в ушкоджених гілках верхньощелепного нерва, активації захисних сил організму і нормалізації порушених функцій вводили периневрально, шляхом ін'єкційного доступу до підочноямкового та вилично-лицевого отворів розчину гомеопатичного препарату «Траумель С» - по 2,2 мл через добу. Курс лікування - 2-3 тижні. Місцево також призначали сеанси УВЧ-терапії.

Статистичну обробку отриманих результатів досліджень проводили за допомогою комп’ютерної програми статистичних обчислень Statistica 8.

Результати досліджень та їх обговорення. У 12 хворих, в яких перелом дна очниці не супроводжувався зміщенням кісткових відламків, або воно було слабовираженим, ми виявили легкий ступінь ушкодження підочноямкового нерва (нейрапраксію). Променеве дослідження зафіксувало у 7 пацієнтів проходження лінії перелому через підочноямковий канал чи підочноямкову борозну (рис. 3). 3а рентгенологічною класифікацією G. F. Fueger та A. T. Milauskas, хворі мали другий, четвертий та шостий типи переломів кісток дна очниці. У них діагностували під час електросенсометрії зниження чутливості шкіри в проекції підочноямкового отвору на боці ураження - $(52,4 \pm 3,7)$ мкА $(\mathrm{p}<0,05)$ та чутливості пульпи зубів верхньої щелепи (різців, ікол та премолярів) - ЕОД $(24,9 \pm 1,8)$ мкА (p<0,01). Якщо

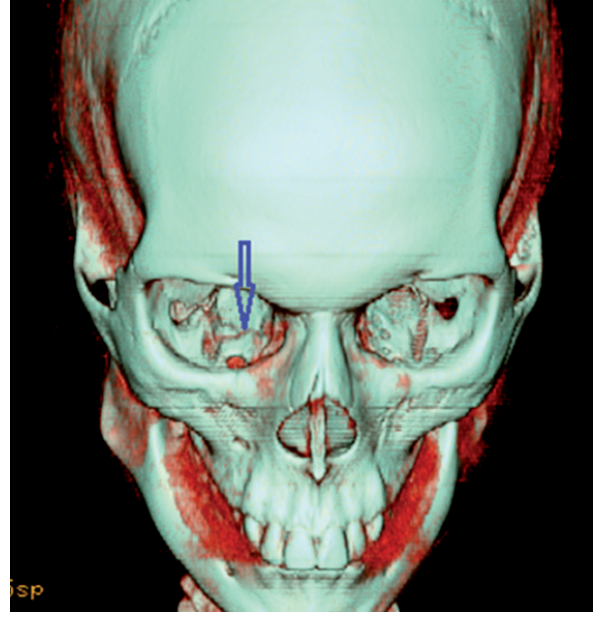

Puc. 3. Комп’ютерна томограма лицевого черепа в 3 D-реконструкції. У хворого діагностовано ізольований перелом нижньої стінки очниці без зміщення кісткових відламків (показано стрілкою). Лінія перелому проходить через підочноямкову борозну (шостий рентгенологічний тип перелому дна очниці за класифікацією G. F. Fueger та А. Т. Milauskas).

лінія перелому проходила через нижню очноямкову щілину (5 випадків), у таких пацієнтів, крім того, виявляли нейрапраксію гілок виличного нерва. Порушення функції вказаних нервів було зумовлено їх компресією гематомою, набряком, прилеглих до нервів, тканин. При клінічному обстеженні періорбітальної ділянки в них виявляли помірний чи рідше виражений ступінь крововиливу (за Mohsen Rajati et al.). Вміст у крові нейронспецифічної енолази не виходив за верхню межу норми - $(15,9 \pm 1,4)$ нг/мл (р>0,05). Сенсорні розлади тканин середньої зони обличчя у цих хворих мали тимчасовий характер. Після проведеного курсу комплексної терапії із застосуванням схеми місцевого впливу на вогнище травматичного ураження, розпрацювали, яку ми швидше на 2-3 доби, ніж при традиційних методах лікування, зменшувався набряк м’яких тканин очниці та розсмоктувались гематоми. Чутливість підочноямкового та виличного нервів повністю відновлювалася через 3-4 тижні від початку лікування.

У 7 пацієнтів діагностовано значне порушення функції підочноямкового та виличного нервів (аксонотмезис), що стало причиною появи виражених сенсорних розладів у м'яких тканинах підочної й виличної ділянок - ЕП шкіри обличчя $(68,9 \pm 4,7)$ мкА $(p<0,01)$, в зубах верхньої щелепи на боці ушкодження - ЕОД зубів $(45 \pm 3,5)$ мкА. При клінічному обстеженні періорбітальної ділянки в них у всіх випадках виявляли виражений ступінь крововиливу (за 
Mohsen Rajati et al.). Серед причин виникнення стійкої нейропатії гілок верхньощелепного нерва були: ушкодження кістковими відламками оболонки та волокон нервів, їх компресія гематомою, запальним ексудатом. Дані, отримані при комп’ютерній томографії, повністю корелювали з результатами клініко-електрофізіологічної діагностики. Перелом кісток дна очниці супроводжувався значним зміщенням ї відламків у бік верхньощелепного синуса (рис. 4).

У крові таких хворих зростала концентрація нейронспецифічної енолази, що виходила за верхню межу норми - $(20,6 \pm 1,7) \mathrm{Hг} / \mathrm{Mл}$ $(\mathrm{p}<0,05)$.

У цієї категорії пацієнтів чутливість м’яких тканин середньої зони обличчя та зубів верхньої щелепи (різців, ікол та премолярів) на боці ураження у більшості випадків відновлювалася в повному обсязі від 1,5 до 2-х місяців після хірургічної реконструкції дна очниці та проведеного курсу комплексної медикаментозної терапії (рис. 5). На тлі нейротропного лі-

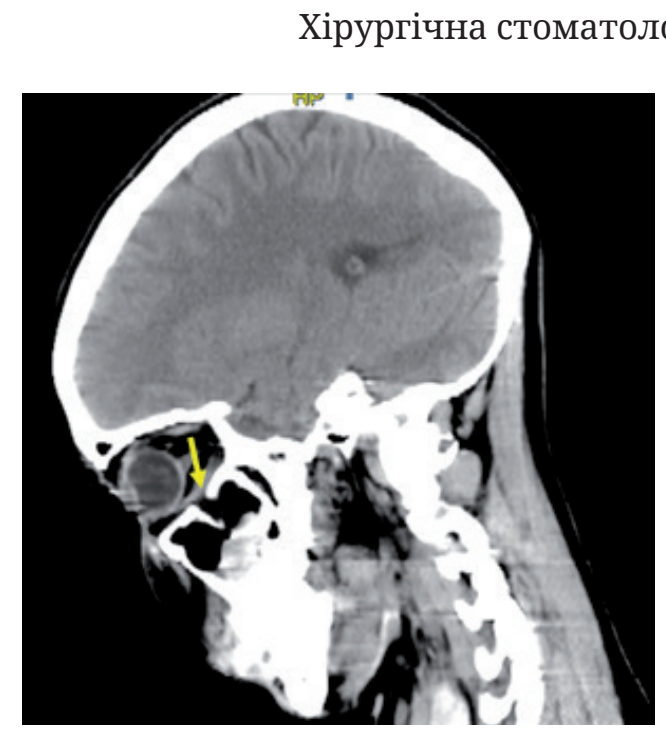

Puc. 4. Комп’ютерна томограма лицевого черепа у хворого з ізольованим переломом дна очниці. Лінія перелому проходить через дно очниці. Кісткові відламки та м'які тканини дна очниці зміщені у бік верхньощелепного синуса (показано стрілкою).

кування поступово нормалізувались показники вмісту в крові нейронспецифічної енолази (рис. 6), що прямо корелювало із даними елек-
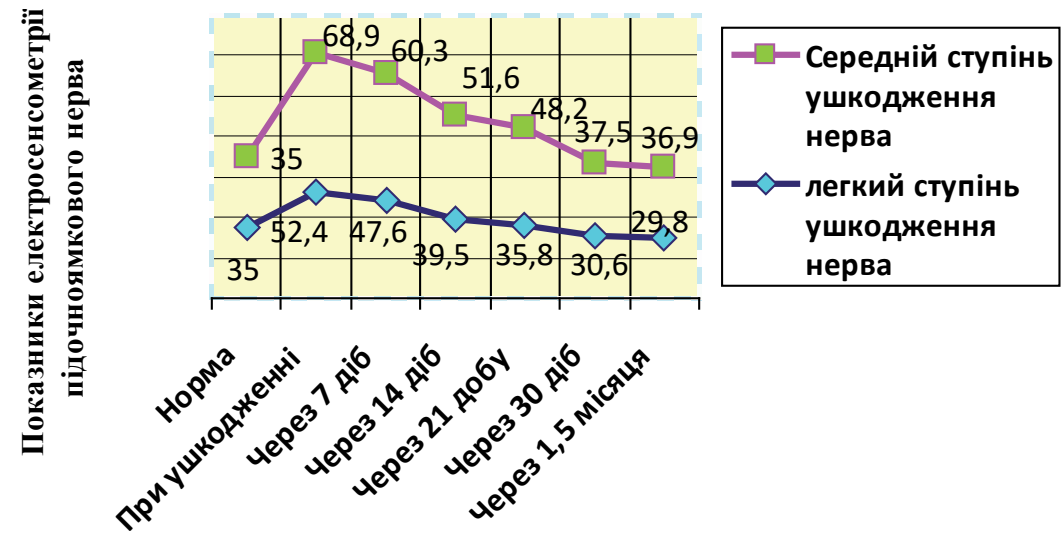

Термін спостереження

Puc. 5. Динаміка показників електросенсометрії підочноямкового нерва залежно від ступеня його ушкодження під час перелому кісток дна очниці.

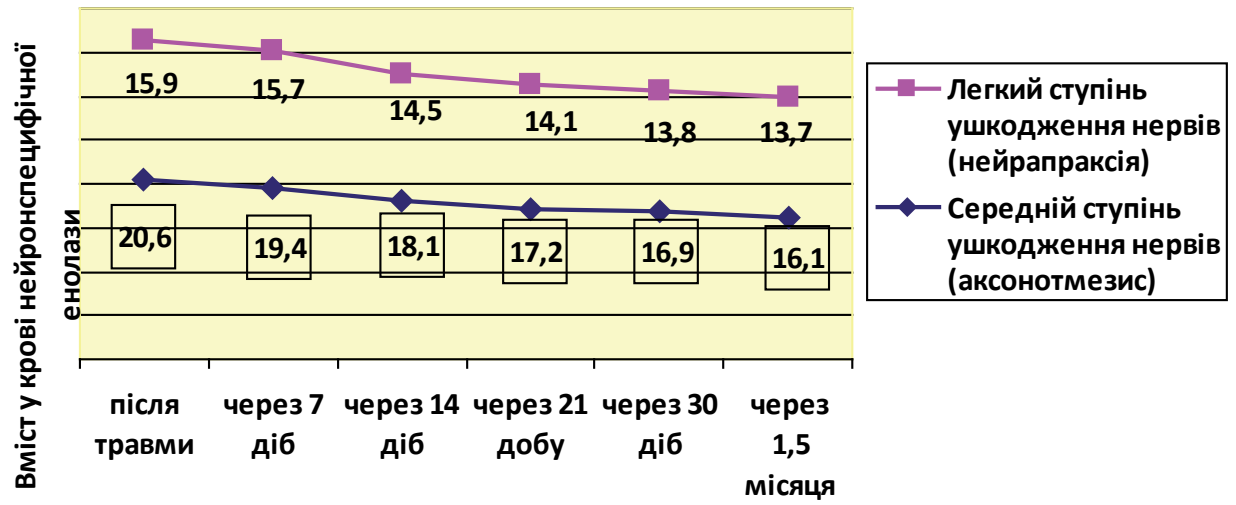

Puc. 6. Динаміка вмісту в крові нейронспецифічної енолази при травматичній нейропатії підочноямкового та виличного нервів на тлі їх лікування. 
тродіагностики чутливості досліджуваних гілок верхньощелепного нерва. Концентрація цього біохімічного маркера нервової тканини у крові хворих наближалась до норми на 30 добу від початку лікування травматичного невриту підочноямкового та виличного нервів $(16,9 \pm 1,3) \mathrm{Hг} / \mathrm{Mл}(\mathrm{p}>0,05)$.

Висновки. Застосування електрофізіологічних тестів та дослідження в крові маркера ушкодження нервової тканини - нейронспе-

\section{Список літератури}

1. Николаенко В. П. Орбитальные переломы : руководство для врачей / В. П. Николаенко, Ю. С. Астахов // СПб. : Эко-Вектор, 2012. - 436 с.

2. Малиновская Н. А. Хирургическое лечение переломов дна и внутренней стенки глазницы с выпадением и ущемлением мягких тканей в зоне перелома у детей : дисс... канд. мед. наук : 14.01.07 / Малиновская Наталья Антоновна. - СПб., 2014. - 130 с. 3. Cruz A. A. Epidemiology and management of orbital fractures / A. A. Cruz, G. C. Eichenberger // Curr. Opin. Ophthalmol. - 2004. - Vol. 15, No. 5. - P. 416-421.

4. Chang E. W. Orbital floor fracture management / E. W. Chang, S. Manolidis // Facial Plast. Surg. - 2005. Vol. 21, No. 3. - P. 207-213.

5. Maxillofacial fractures in the province of Latina, Lazio, Italy: review of 400 injuries and 83 cases P.Arangio, V.Vellone, U.Torre [et al.]//J.Craniomaxillofac. Surg. - 2014. - No. 42 (5). - P. 583-587.

6. Ocular and periocular injuries associated with an isolated orbital fracture depending on a blunt cranial trauma: anatomical and surgical aspects / H. S. Karabekir, N. Gocmen-Mas, E. Emel [et al.] // J. Craniomaxillofac. Surg. - 2012. - No. 40 (7). - P. 89-93.

7. Hwang K. Do we have to dissect infraorbital nerve from periorbita in orbital floor fracture? / K. Hwang, J. H. Hwang // J. Craniofac Surg. - 2009. - No. 20 (4). P. 1260-1262.

8. Hypoesthesia of the infraobital nerve as the only symptom of a blowout orbital fracture: Report of a case and review of the literature / S. Papouliakos, V. Lachanas, G. Karatzias [et al.] // The Internet Journal of Otorhinolaryngology. - 2006. - Vol. 7, No. 1. - P. 4.

9. Analysis of complications after surgical repair of orbital fractures / M. Brucoli, F. Arcuri, R. Cavenaghi, A. Benech // J. Craniofac. Surg. - 2011. - Vol. 22, No. 4. P. 1387-1390.

10. Variations in the topography of the infraorbital canal/groove complex: a proposal for classification and its potential usefulness in orbital floor surgery / A. Przygocka, J. Szymański, E. Jakubczyk, K. Jędrzejewski [et al.] // Folia Morphol. - 2013. - Vol. 72, No. 4. - P. 311-317. 11. Anatomical study of the intraosseous pathway of the infraorbital nerve / Dennis C. Nguyen, Scott J. Farber, Grace T. Um [et al.] // J. Craniofac Surg. - 2016. - No. 27 (4). - P. 1094-1097. цифічної енолази дозволяють виявити ступінь ушкодження підочноямкового та виличного нервів у хворих з ізольованими переломами дна очниці. Місцеве застосування фібринолітичного препарату «Гемаза» та гомеопатичного засобу «Траумель С» прискорює розсмоктування гематоми очниці, швидше ліквідуються клінічні симптоми запалення та покращує ефективність лікування невриту підочноямкового й виличного нервів.

12. Hoke A. Mechanisms of disease: what factors limit the success of peripheral nerve regeneration in humans? / A. Hoke // Nat. Clin. Pract. Neurol. - 2006. - No. 2. P. 448-454.

13. Mohsen R. Periorbital ecchymosis and subconjunctival hemorrhage following ear surgery / R. Mohsen, B. Mehdi, K. Kamran // Hindawi Publishing Corporation ISRN Otolaryngology. - 2013. - Article ID 791068, 4 pages.

14. Classification and surgical management of orbital fractures: experience with 111 orbital reconstructions / S. Manolidis, B. H. Weeks, M. Kirby [et al.] // J. Craniofac. Surg. - 2002. - No. 13(6). - P. 726-737.

15. Campbell William W. Evaluation and management of peripheral nerve injury / William W. Campbell // Clinical Neurophysiology. - 2008. - No. 119. - P. 1951-1965.

16. Нечаева Н. К. Электрофизиологические исследования в диагностике невропатий нижнего альвеолярного нерва / Н. К. Нечаева, С. В. Тарасенко // Российский стоматологический журнал. - 2014. № 5. - C. 25-28.

17. Zygomaticofacial, zygomaticoorbital and zygomaticotemporal foramina: Anatomical study / M. Loukas, D. Gueorguieva Owens, R. Shane Tubbs [et al.] // Anatomical Science International. - 2008. - No. 83(2). - P. 77-82.

18. Three-dimensional courses of zygomaticofacial and zygomaticotemporal canals using micro-computed tomography in Koreans / H. S. Kim, J. H. Oh, D. Y.Choi [et al.] // J. Craniofac. Surg. - 2013. - No. 24. - P. 1565-1568. 19. Hwang K. Cutaneous Distribution of Infraorbital Nerve / K. Hwang, M. S. Suh, I. H. Chung // Journal of Craniofacial Surgery. - 2004. - Vol. 15, Issue 1. - P. 3-5. 20. Senthil K. S. Incidence and location of zygomaticofacial foramen in adult human skulls / K. S. Senthil, D. Kesavi // International Journal of Medical Research \& Health Sciences. - 2014. - No. 3 (1). - P. 80-83.

21. Kun Hwang. Cutaneous distribution of infraorbital nerve / Hwang Kun, Suh Min Sung, Chung In Hyuk // Journal of Craniofacial Surgery. - 2004. - Vol. 15, Issue 1. - P. 3-5.

22. Topographic distribution area of the infraorbital nerve / Kyung-Seok Hu, Jinny Kwak, Ki-Seok Koh [et al.] // Surgical and Radiologic Anatomy. - 2007. - Vol. 29, Issue 5. - P. 383-388. 


\section{References}

1. Nikolayenko, V.P. \& Astakhov, Yu.S. (2012). Orbitalnyye perelomy. Rukovodstvo dlya vrachey [Orbital fractures. Manual for doctors]. Eko-Vektor. Saint-Peterburg [in Russian].

2. Malinovskaya, N.A. (2014). Khirurgicheskoye lecheniye perelomov dna i vnutrenney stenki glaznitsy $\mathrm{s}$ vypadeniyem i ushchemleniyem myagkikh tkaney $\mathrm{v}$ zone pereloma $u$ detey [Surgical treatment of fractures of the bottom and inner wall of the orbit with loss and infringement of soft tissues in the fracture zone in children]. Candidate's thesis. Saint-Petersburg [in Russian]. 3. Cruz, A.A. \& Eichenberger, G.C. (2004). Epidemiology and management of orbital fractures. Curr. Opin. Ophthalmol, 15, 5, 416-421.

4. Chang, E.W. \& Manolidis, S. (2005). Orbital floor fracture management. Facial Plast. Surg., 21, 3, 207-213. 5. Arangio, P., Vellone, V., Torre, U., Calafati, V., Capriotti, M. \& Cascone, P. (2014). Maxillofacial fractures in the province of Latina, Lazio, Italy: review of 400 injuries and 83 cases. J. Craniomaxillofac Surg., 42 (5), 583-587.

6. Karabekir, H.S., Gocmen-Mas, N., Emel, E., Karacayli, U., Koymen, R., Atar, E.K. \& Ozkan, N. (2012). Ocular and periocular injuries associated with an isolated orbital fracture depending on a blunt cranial trauma: anatomical and surgical aspects. J. Craniomaxillofac. Surg., 40 (7), 89-93.

7. Hwang, K. \& Hwang, J.H. (2009). Do we have to dissect infraorbital nerve from periorbita in orbital floor fracture? J. Craniofac. Surg., 20 (4), 1260-1262.

8. Papouliakos, S., Lachanas, V., Karatzias, G., Koufakis, D. \& Sandris, V. (2006). Hypoesthesia of the infraobital nerve as the only symptom of a blowout orbital fracture: report of a case and review of the literature. The Internet Journal of Otorhinolaryngology, 7, 1, 4.

9. Brucoli, M., Arcuri, F., Cavenaghi, R. \& Benech, A. (2011). Analysis of complications after surgical repair of orbital fractures. J. Craniofac Surg., 22, 4, 1387-1390.

10. Przygocka, A., Szymański, J., Jakubczyk, E., Jędrzejewski, K., Topol, M. \& Polguj, M. (2013). Variations in the topography of the infraorbital canal/groove complex: a proposal for classification and its potential usefulness in orbital floor surgery. Folia Morphol, 72, 4, 311-317.

11. Nguyen, D.C., Farber, S.J., Um, G.T., Skolnick, G.B., Woo, A.S. \& Patel, P. (2016). Anatomical Study of the Intraosseous Pathway of the Infraorbital Nerve. J.
Craniofac. Surg., 27 (4), 1094-1097.

12. Hoke, A. (2006). Mechanisms of disease: what factors limit the success of peripheral nerve regeneration in humans? Nat. Clin. Pract. Neurol., 2, 448-454.

13. Mohsen, R., Mehdi, B. \& Kamran, K. (2013). Periorbital ecchymosis and subconjunctival hemorrhage following ear surgery. Hindawi Publishing Corporation ISRN Otolaryngology. Article ID 791068, 4 p.

14. Manolidis, S., Weeks, B.H., Kirby, M., Scarlett, M. \& Hollier, L. (2002). Classification and surgical management of orbital fractures: experience with 111 orbital reconstructions. J. Craniofac. Surg., 13 (6), 726737.

15. Campbell, W.W. (2008). Evaluation and management of peripheral nerve injury. Clinical Neurophysiology, 119, 1951-1965.

16. Nechayeva, N.K. \& Tarasenko, S.V. (2014). Elektrofiziologicheskiye issledovaniya $\mathrm{v}$ diagnostike nevropatiy nizhnego alveolyarnogo nerva [Electrophysiological studies in the diagnosis of neuropathies of the lower alveolar nerve]. Rossiyskiy stomatologicheskiy zhurnal - Russian Dental Journal, 5, 25-28 [in Russian].

17. Loukas, M., Gueorguieva, D., Owens, R., Tubbs, Sh., Spentzouris, G., Elochukwu, A., Jordan, R. (2008). Zygomaticofacial, zygomaticoorbital and zygomaticotemporal foramina: Anatomical study. Anatomical Science International, 83 (2), 77-82.

18. Kim, H.S., Oh, J.H., Choi, D.Y., Lee, J.G., Choi, J.H., Hu, K.S., ... Yang. H.M. (2013). Three-dimensional courses of zygomaticofacial and zygomaticotemporal canals using micro-computed tomography in Koreans. J. Craniofac. Surg., 24, 1565-1568.

19. Hwang, K., Suh, M.S. \& Chung, I.H. (2004). Cutaneous Distribution of Infraorbital Nerve.Journal of Craniofacial Surgery, 15, 1, 3-5.

20. Senthil, K.S. \& Kesavi, D. (2014). Incidence and location of zygomaticofacial foramen in adult human skulls. International Journal of Medical Research \& Health Sciences, 3 (1), 80-83.

21. Kun H., Sung, S.M. \& Hyuk, Ch.I. (2004). Cutaneous Distribution of Infraorbital Nerve. Journal of Craniofacial Surgery, 15, 1, 3-5.

22. Hu, K.-S. Kwak, J., Koh, K.-S., Abe, Sh., Fontaine, Chr. \& Kim, H.-J. (2007). Topographic distribution area of the infraorbital nerve. Surgical and Radiologic Anatomy, $29,5,383-388$.

Отримано 05.06.18 